\title{
Development and characterization of microsatellite molecular markers for the investigation of polydomy in a Cerrado savanna ant, Camponotus leydigi ( Formicidae: Formicinae)
}

\author{
Salatiel Gonçalves-Neto*, Marianne Azevedo-Silva, Alessandra S.M. Lemos, Hélio Soares Jr, Anete P. Souza \\ Paulo S. Oliveira.
}

\begin{abstract}
Polydomy occurs when an ant colony occupies at least two spatially separated but socially connected nests. The identification of polydomy in ant colonies is important to understand ant life history, evolutionary success, and biotic and abiotic impacts on the environment. Several methodologies are used for the correct delimitation of the borders of the colonies and, therefore, in the identification of colonies with polidomous structure, these limits can be determined according to behavioral, spatial and genetic approaches. In the present study we develop and characterize microsatellite markers in order to complement ecological results that suggest the existence of polydomy in the cerrado ant species, Camponotus leydigi.
\end{abstract}

\section{Key words:}

Ants, behavior, microsatellite.

\section{Introduction.}

Camponotus leydigi (Forel) is a widely distributed ant species in the Neotropics and is frequently found in the Brazilian Cerrado savanna interacting with plants and other insects. Recent behavioral and spatial data supported the existence of polydomy in C. leydigi colonies in the cerrado reserve at Itirapina-SP (southeast Brazil) ${ }^{1}$. Polydomous ants (i.e. physically separated but socially connected nests) are ecologically successful due to diet diversification and increased rate of resource exploitation (through area expansion and/or increased foraging efficiency). Delimitation of polydomous colonies requires the use of several methods, including behavioral, spatial, and genetic approaches ${ }^{2}$.

In the present study we develop and characterize microsatellite markers in order to, through molecular data, complement ecological results that suggest the existence of polydomy in Camponotus leydigi.

\section{Results and Discussion}

Six $C$. leydigi workers from the same colony were used to obtain a microsatellite-enriched library. According to this method, repetitive sequences were captured with (CT) 8 and $(\mathrm{GT})_{8}$ biotin-linked probes, with subsequent recovery by streptavidin magnetic-coated beads ${ }^{3}$. Polymorphic microsatellite markers are being selected to analyze the relatedness among workers from ten nests belonging to a single $C$. leydigi polydomous colony from the cerrado reserve at Itirapina-SP (southeast Brazil). Thirteen microsatellite loci were obtained (Chart 1) from each ten successfully amplified after polymerase chain reactions (PCR). Thirty different $C$. leydigi genotypes were used for loci characterization, such as their polymorphism content.

Chart 1. Microsatellite loci developed for $C$. leydigi with respective motifs and expected sizes.

\begin{tabular}{|c|c|c|}
\hline Locus & Motif & Expected Size \\
\hline Cll & $(\mathrm{gg})_{4 \ldots} \ldots(\mathrm{tg})_{42} \ldots(\mathrm{ga}) 6$ & 241 \\
\hline Cl2 & $(\mathrm{ta})_{4 \ldots} \ldots(\mathrm{ta})_{4 \ldots} \ldots(\mathrm{at})_{3 \ldots} \ldots(\mathrm{tg})_{30} \ldots(\mathrm{at})_{3}$ & 270 \\
\hline Cl4 & $\left.(\mathrm{ta}))_{8 \ldots}(\mathrm{tg})_{14 \ldots} \ldots(\mathrm{gt})\right)_{3} \ldots(\mathrm{gt})_{10}$ & 225 \\
\hline Cl5 & $(\mathrm{gt}) 25$ & 154 \\
\hline $\mathrm{Cll0}$ & $(\mathrm{ac})_{7 \ldots} \ldots(\mathrm{ca})_{22 \ldots} \ldots(\mathrm{at})_{3}$ & 270 \\
\hline $\mathrm{Cll} 7$ & $(\mathrm{at})_{3 \ldots}(\mathrm{ag})_{3 \ldots} \ldots(\mathrm{at})_{3 \ldots} \ldots(\mathrm{ta})_{3 \ldots}(\mathrm{tg})_{16 \ldots} \ldots(\mathrm{tgta})_{3}$ & 270 \\
\hline $\mathrm{Cl} 20$ & (ac) $9 \ldots(\mathrm{ta})_{3} \ldots(\mathrm{ta})_{3}$ & 304 \\
\hline Cl22 & $(\mathrm{gt}) 7 \ldots(\mathrm{tg})_{7}$ & 274 \\
\hline Cl26 & $(\mathrm{taa})_{3}$ & 104 \\
\hline $\mathrm{Cl} 36$ & $(\mathrm{tc}) 5 \ldots(\mathrm{cg})_{3} \ldots(\mathrm{ct})_{25}$ & 361 \\
\hline $\mathrm{Cl39}$ & $(\mathrm{ttta})_{3}$ & 136 \\
\hline $\mathrm{Cl42}$ & $(\mathrm{tcc}) 4$ & 146 \\
\hline Cl49 & $(\mathrm{ca})_{4} \ldots(\mathrm{ac})_{4 \ldots}(\mathrm{ca})_{3} \ldots(\mathrm{ca})_{3} \ldots(\mathrm{cg})_{3}$ & 217 \\
\hline
\end{tabular}

\section{Conclusions}

We successfully developed microsatellite markers for $C$. leydigi, which will allow future studies on population genetics and ecology of Camponotus ants in Cerrado, including behavioral, dispersal and conservation investigations.

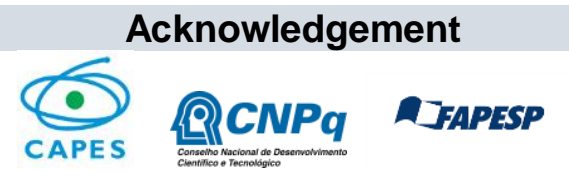

${ }^{1}$ Soares, H. Jr. História natural, comportamento e ecologia de Camponotus leydigi forel, 1886 (Hymenoptera: Formicidae) em vegetação de cerrado. 2018. Dissertação (Mestrado em Biologia Animal) - Instituto de Biologia, Universidade Estadual de Campinas, Campinas.

${ }^{2}$ Ellis, S.; Procter, D. S.; Buckham-Bonnet, P. e Robinson, E. J. H. Insectes Soc. 2017, 64, 9 .

${ }^{3}$ Billotte, N.; Lagoda, P. J. L.; Risterucci, A. M. e Baurens, F. C. Fruits. 1999 $54,277$. 